109 ミスト流中における衝撃波と境界層の干渉の 物体光透過フィルターを用いた可視化観察

埼玉大院 清水武司 ${ }^{\circ}$ 、埼玉大工 平原裕行、 埼玉大工 川橋正昭、埼玉大工 紐井健司

\title{
Visualization of Interaction between Shock Wave and Boundary Layer in Mist by Using Objective Light Pass Filter
}

\author{
Tākeshì-SHIMIZU* , Hiroyuki HIRAHARA**, \\ Masaaki KAWAHASHI"* and Kenji HOSOr**
}

Optical visualization of interaction between a shock wave and boundary layer in mist has been carried out by using objective light pass filter, by which a perfect shadowgraph can be obtained. The intensity with the filter is proportional to the source density which has a gradient of spatial light diffraction coefficient. Therefore we can obtain a mist density from the image of photograph experimentally obtained. Experimental photograph shows a detailed flow field image. Compression or expansion wave also visualized with the present method. The interaction between a shock wave and thermal boundary layer in mist has been investigated in detail experimentally.

\section{1.はじめに}

ミストの様に微細な液滴が浮遊する二相媒質中を衝撃波が伝ぱする場合、通常、衝撃波 の背後において相平衡の条件が崩れ、非平衡な状態へと移行する。これに伴い、気相から 液相への熱伝達、運動量輸送、相変化に伴う液相から気相への質量移送が発生し、衝撃波 背後にそれぞれの輸送現象に対応した緩和領城が形成される ${ }^{1)}$ 。れら複数の緩和過程は、 衝撃波の伝ぱ速度、液滴の数密度、及び液滴直径に依存する。例えば、標準状態で発生す る霧のような媒質の場合、液滴の直径は 0.1 から $10 \mu \mathrm{m}$ のオーダーで、このような二相流中 を衝撃波が伝ぱするときには、運動量緩和が最も早く進行し、次いで熱的緩和、相変化の 緩和が継続して進行する。実験的にこれらの過程を調べようとする場合、光学的な計測法 が有力な手段となるが、これには大きな寒験誤差やゆらぎが重畳するため、ノイズ除去に 十分配虑する必要がある。現在、このような光学計測はノイズ除去の必要性のため、ポイ ント計測が主体的であり、非定常流れに対して 2 次元的な計測を行った例は極めて少ない。 さらに、上述したようなミスト中を衝撃波が伝ぱする流れ場においては、壁面に発達する 速度境界層あるいは温度境界層との干涉により、現象が極めて複雑になり、詳細に流れ場 を可視化して調べることは必須の課題である。本研究は、流れ場を詳細に調べ、より定量 的な可視化像を得るために、通常の可視化手法に若干の改良を加え、特に衝撃波と境界層 の干渉について調べたのでここに報告する。

\footnotetext{
- Graduate School of Science and Engineering, Saitama University, 255 Shimo-okubo, Urawa, Saitama.

"* Faculty of Engineering, Saitama University
} 


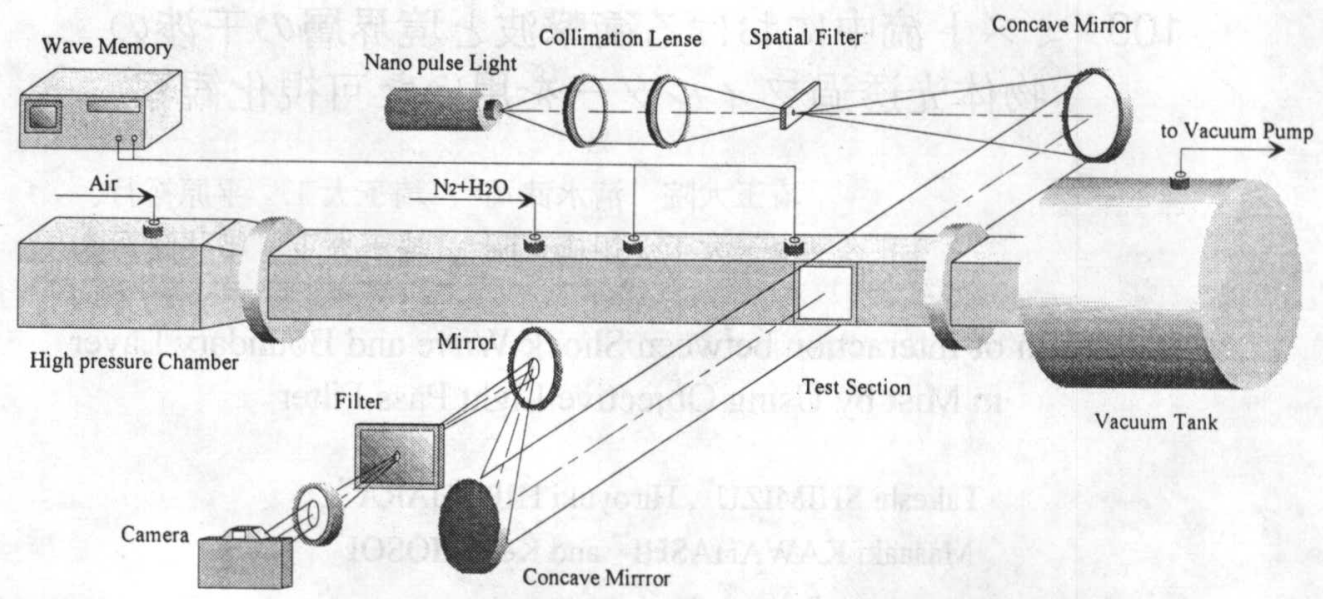

2.実験装置及び可視化手法

Fig.1 Experimental Setup

本実験に用いた実験装置及び光学系の配置を Fig.1 に示す。実験装置本体、及び実験手順 は、文献 ${ }^{2)}$ と同様であるので省略する。初期絶対湿度、浮遊液滴の直径はそれぞれ、 $2 \times$ $10^{-2} \mathrm{~kg} / \mathrm{kg}$ 、約 $1 \mu \mathrm{m}$ である。ミスト中を伝ぱする衝撃波のマッ八数 Ms は 2.6 から 1.6 の範囲 で変化させた。光学系については、ミスト中の流れを観察できるように若干の変更を行っ た。基本的な配置はシュリーレン法と同様である。測定部を平行光が通過するよう設定し、 通過した平行光は凹面鏡により一度焦点を結ぶ。この部分の焦点像を、予めリバーサルフ イルムにより撮影し、現像後、もとの位置に戻して物体光のみが通過する空間フィルター を構成する。今、測定対象の屈折率を $n(x, y, z)$ とする。このフィルターを用いることによ り、屈折率の空間勾配 $\partial n / \partial x, \partial n / \partial y \ldots$ が存在するときの光の屈折の影響のほとんどを除 去することができると考えられる。即ち、このフィルターにより、屈折率が空間的に変動 する部分はほとんど影として観察でき、その意味では高感度のシャドウグラフ法として考 えることができる。本実験で、このフィルターを用いた理由は以下による。一つの理由は、 液滴が気体中に十分に疎な状態で存在するなら ば、観察場に存在する液滴から散乱される光を 除去し、こうして得られた画像を処理すること により、液滴の数密度変化に関する情報を得る ことができると考えられることである。ところ で、液滴はおよそ $190 \mathrm{~K}$ の気体中に浮遊し、衝 撃波管の壁面から熱伝達が生じ、壁面近傍に温 度境界層が形成される。この境界層内では蒸気 圧が飽和蒸気圧よりも低いため、凝縮による液 滴は形成されない。そこで、もう一つの理由は、 今回の実験の目的の一つであるこの境界層と衝 撃波との干渉を観察するために、液滴の影像を 的確にとらえ、液滴の流動状態をより詳細に把

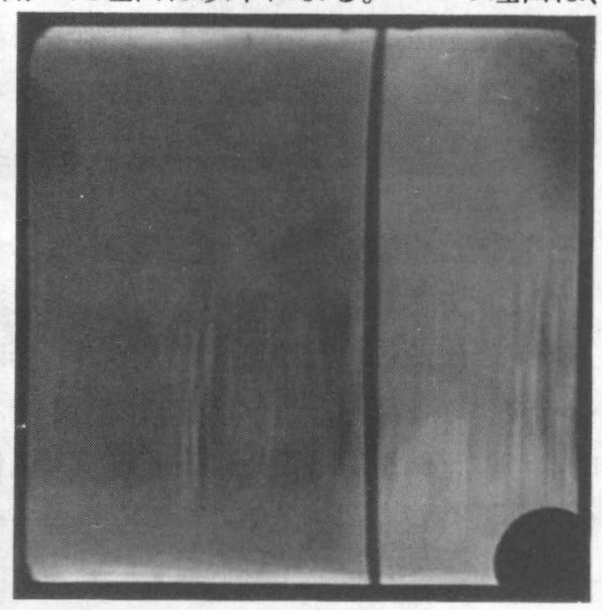

(a) $\mathrm{Ms}=1.6,160 \mathrm{~ms}$

Fig. 2 Shadow Image 
握することができると考えたことである。

\section{3.実験結果及び考察}

初めに、光学観察の結果について述べる。今 回の実験により得られた写真を Fig.2に示す。実 験条件は、順にマッハ数 $\mathrm{Ms}=1.6,2.0,2.6,2.6$ であ る。衝撃波の前方に存在する液滴について、予 備実験により求めた結果によれば、直径はおよ そ $1 \mu \mathrm{m}$ である。測定部中央で行った光散乱計測 結果からは、断熱膨張による液滴の核生成は第 1 隔膜の破膜から、およそ $20 \mathrm{~ms}$ 後に発生し、流れ は $150 \mathrm{~ms}$ 後にほぼ定常状態に達し、およそ $1200 \mathrm{~ms}$ 持続するとの結論が得られている。霧の 分布状態は衝撃波管管壁からの熱伝達の影響を 受けるため、第 1 隔膜破膜後、可能な限り短い 経過時間内に衝撃波を伝ぱさせることが望まし い。ここに示した写真の(a)-(c)は、第 1 隔膜の破 膜後、 $160 \mathrm{~ms}$ 経過した時のものであり、この設 定值は上述の理由による。(d)は $200 \mathrm{~ms}$ 経過した 時のものである。衝撃波背後の気流は、衝撃波 によって圧縮された熱気流であるため、液滴の 数密度もほぼ密度の増加に比例して増加すると 考えられる。写真の観察領域上下に見られる壁 近傍の白い部分は、管壁からの熱伝達による温 度境界層である。この領域は液滴発生後、時間 とともに拡大し、熱伝達により液滴が蒸発して いる過程が、光学観察から明確に確認できた。

衝撃波マッハ数の変化による、衝撃波と境界 層の干渉過程の影響について以下に述べる。初 めに、衝撃波の波形について明記しておく必要 がある。いずれの写真においても衝撃波は中央 付近が湾曲している。これは衝撃波が温度境界 層の影響により皿状に変形しているためである。 衝撃波背後の液滴の蒸発過程は、明らかに壁面 境界層の影響を強く受けている。衝撃波のマッ 八数が低いときには、壁面に発達する速度境界 層も、層流的であるように観察される。衝撃波 マッハ数の増加とともに境界層は乱れ、 $\mathrm{Ms}=2.6$

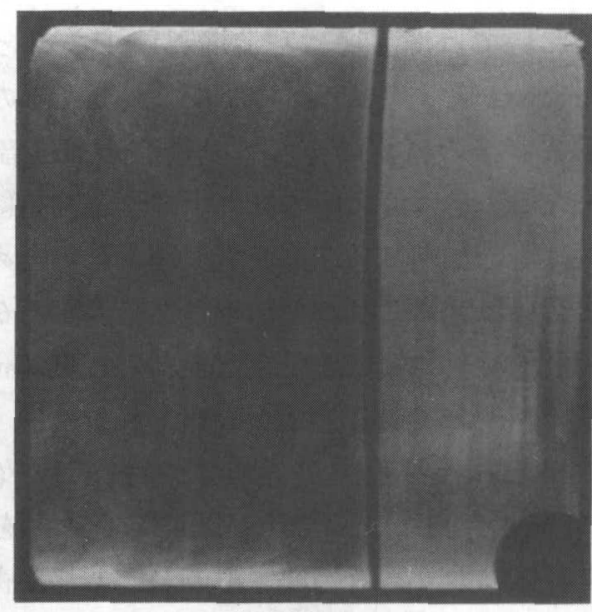

(b) $\mathrm{Ms}=2.0,160 \mathrm{~ms}$

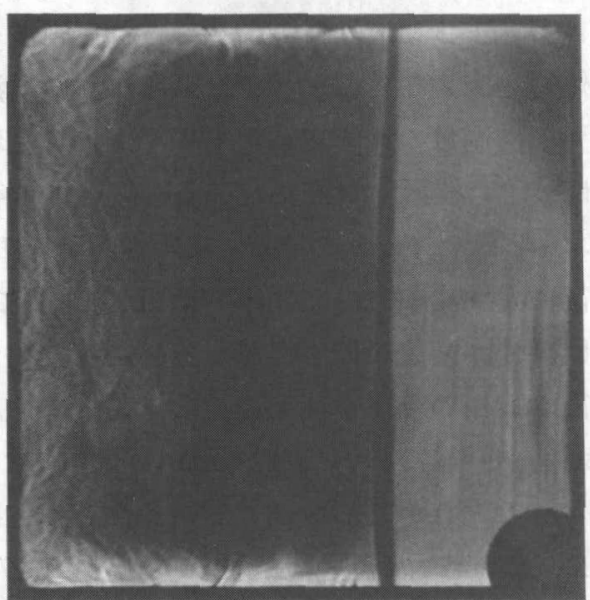

(c) $\mathrm{Ms}=2.6,160 \mathrm{~ms}$

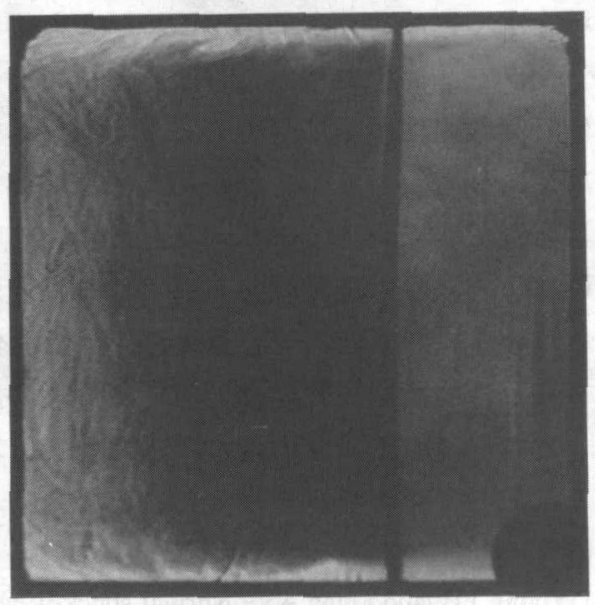

(d) $\mathrm{Ms}=2.6,200 \mathrm{~ms}$

Fig. 2 Shadow Image 
においては境界層は乱流境界層であると判断し てよいと考えられる。ちなみに、Ms=2.0の時の衝 綮波背後の気流の速度は衝撃波上流の音速程度 となる。速度境界層の乱れが増すと同時に、衝撃 波による加熱による蒸発も促進されるため、衝撃 波背後は非常に乱れた状態となる。Ms=2.6の場合、 相変化の緩和領域の長さは、およそ $40 \mathrm{~mm}$ 程度に まで減少していることが観察される。

得られた写真をフィルムスキャナ一(解像度 $2700 \mathrm{dpi}$;今回は $256 \times 256$ pixels にて使用)を用いて 計算機に取り込み処理することにより、液滴数密 度に関するより定量的なデータを得ることがで きる。Fig.3 は、それにより得られた画像を適当な 処理を施すことによって、画像から衝撃波前後の 光の透過量の比を求めたものである。処理の手順

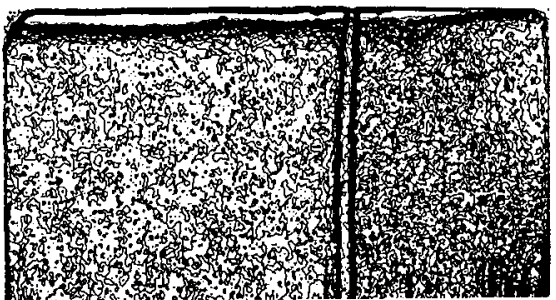

(a) $\mathrm{Ms}=1.6$

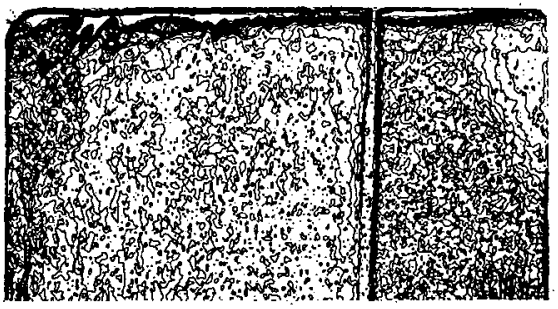

(b) $\mathrm{Ms}=2.6$

Fig. 3 Contour Map of Shadow Image は、予め撮影した霧が存在しないときの写真を基準として、これから光の平均透過量 Ia 求め、次に Fig.2 に対応する画像データの各ピクセルでの值と Ia との相対值 Ib を求め、最 後に衝撃波前方の空間平均値 $\overline{I b}$ 基淮に画像の輝度値を正規化した。結果として得られた 值は、浮遊液滴の半径が十分に小さく、かつ数密度が適当な範囲にあるならば、衝撃波前 後の液相の存在を与える重要な值となる。特に、液滴半径がほとんど変化しない衝撃波の 直前、直後においては、液滴の屈折率や半径には無関係に液滴数密度の比を与えると考え られる。しかし、今回の実験条件では、液滴の数密度は光散乱計測の結果から推定して、 $10^{3}$ 個 $/ \mathrm{mm}^{3}$ (液滴平均距離 $100 \mu \mathrm{m}$ ) であり、測定部は奥行 $80 \mathrm{~mm}$ であるために、液谪の数密 度が十分疎な状態ではないとの結果が得られた。このため、得られた画像は定性的議論の 域を出ていない。さて、ここに示した処理画像は乱れの程度を示すために、得られた画像 データを等高線処理して（原画像はカラー等高線処理）示したものである。画像は定性的 に液滴数密度が増加していることを示している。しかしながら、定量的には予測される輝 度比よりもかなりのずれがある。温度境界層付近は非常に大きな液滴数密度の勾配がある ことが明確に現れている。乱れについて考察すると、マッ八数が大きくなると衝撃波の通 過による液滴の空間的分布にはそれ程変化は見られないものの、境界層との干涉による乱 れは非常に顕著となると言える。今後、本手法をもとに改良を加え、液滴数密度の定量化、 ならびに液滴の蒸発過程と境界層付近の乱れとの関連について詳しく調べる予定である。

おわりに、本実験の遂行に当たって、本学学生の大塩洋祐君に多大なる助力を得た。こ こに記して感謝の意を表する次第である。

参考文献

1)Young,J.B. and Guha,A., Normal shock-wave structure in two phase vapor-droplet flows, J.fluid Mech., Vol.228(1991),243 2)H.Hirahara. and M.Kawahashi., Optical Observation of Mach Reflection of a Partly Dispersed Shock Wave by Sub-Micron Water Droplets in Air, Shock Waves@Marseille III.,(1993),77 